\title{
ON MEDICINA:
}

25 a 27 de Outubro de 2021

ISBN: 978-65-81152-17-8

DOENÇA MENINGOCÓCICA COMPLICADA COM CHOQUE SÉPTICO E COAGULOPATIA EM ADOLESCENTE DE 17 ANOS

Semana Online Científica de Medicina, 1ạ edição, de 25/10/2021 a 27/10/2021

ISBN dos Anais: 978-65-81152-17-8

OLIVEIRA; Gabrielle Cordeiro Beltrão de ${ }^{1}$, NICOLETTI; João Pedro Abrahão 2

\section{RESUMO}

A Doença Meningocócica (DM) é uma infecção bacteriana aguda, causada pela Neisseria meningitidis, altamente fatal, que necessita diagnóstico e intervenção precoce. Sua apresentação clínica varia desde a forma assintomática, até a doença invasiva, como meningococcemia e meningite (com ou sem meningococcemia). O devido caso, trata-se de uma paciente, feminina, 17 anos, com quadro de astenia, febre, náuseas, vômitos, além de rash violáceo em membros inferiores, superiores e face, evoluindo com cefaleia intensa, confusão mental e sinais de irritação meníngea. Ao exame paciente encontrava-se em grave estado geral, rash violáceo em membros inferiores, superiores, face, com necrose de quarto e quinto quirodáctilos direito, pouco colaborativa, confusão mental, rigidez de nuca e hipotensa $(81 \times 41 \mathrm{mmHg})$. Análise de líquor mostrou glicose $<5$ $\mathrm{mg} / 100 \mathrm{ml}$, proteína $346 \mathrm{mg} / 100 \mathrm{ml}$, células nucleadas 10.441 (neutrofilos $85 \% /$ Linfocitos 5\% / Monocitos 10\%). Pesquisa para BAAR e fungo negativos. Isolamento de diplococo gram (-) à microscopia direta. Aglutinação pelo látex ((H.influenza/S.pneumoniae/ N.Meningitidis A/B/C): Neisseria meningitidis C: Positivo. Solicitado avaliação da cirurgia vascular, onde foi sugerido, devido a ausência de perfusão nos membros, amputação do antepé esquerdo. O quadro clínico da paciente seguiu conforme a apresentação clássica da DM, inicialmente com sintomas nãoespecíficos, como febre, sonolência, náuseas, vômitos e irritabilidade, que geralmente se apresentam dentro de 4 a 6 horas seguido de rash purpúrico clássico, dor e rigidez de nuca, que geralmente aparecem depois de 12 horas. A coagulopatia apresentada, está associada à trombose microvascular, lesão endotelial e risco elevado de sangramento. Infelizmente, a maioria dos casos de DM é diagnosticada após o aparecimento dos sinais tardios.

PALAVRAS-CHAVE: Doença Meningocócica, necrose, amputacão 